\title{
Comparison of the Effects of Sugar-free Solutions, Cola, Mouthwash on the Surface Hardness and Roughness of Temporary Crown Materials
}

\author{
NURAN YANIKOGLU ${ }^{1}$ ORCID ID: 0000-0001-7677-1248, \\ ZEYNEP YESIL DUYMUS ${ }^{\mathbf{1}}$, ORCID ID: 0000-0002-9767-0080 \\ SEBAHAT FINDIK AYDINER ${ }^{2 *}$ ORCID ID:0000-0003-3476-5135 \\ ${ }^{1}$ Department of Prosthodontics, Faculty of Dentistry, Atatürk University, Erzurum, Turkey \\ ${ }^{2}$ Dentist, Ministry of Health Yıldırım Beyazıt University Yenimahalle Training and Research Hospital, Yenimahalle/Ankara, \\ Turkey
}

\begin{abstract}
The aim of this study is to investigate the effect of polishing with different solutions on the surface roughness and hardness of two different polymethylmethacrylate temporary restoration materials. In the study, two different temporary crown materials prepared in the CAD / CAM system and prepared by the traditional method were used to test a total of 224 pieces of $10 \mathrm{~mm}$ diameter and $2 \mathrm{~mm}$ thickness. After the surface roughness and micro hardness values were measured, samples were randomly divided into seven groups among themselves; After waiting $24 \mathrm{~h}, 1$ and 3 weeks, values were measured again. Data were evaluated using 3-way analysis of variance (ANOVA) and Tukey HSD test. The temporary restorative materials' surface hardness and roughnesses are important to be able to stay in oral cavity without any changes. And it is also important to determine which of the materials (prepared by temporary conventional materiels or by the CAD/CAM) are less effected by the liquids in oral cavity.
\end{abstract}

Keywords: polymethylmethacrylate, temporary dental restorations, surface properties, mouthwashes, CAD-CAM, sugar acids

\section{Introduction}

A temporary restoration must be made immediately after tooth preparation to protect the cut tooth from thermal bacterial and chemical effects. These restorations must have the strength to withstand masticatory forces, have good marginal fit and esthetics, and be able to protect pulp and periodontium. Temporary restorative materials have low fracture resistance. Consequently, the use of restorations with improved physical properties is recommended, especially in cases of long-body fixed partial prosthesis, in the treatment of Temporomandibular Joint (TMJ) diseases requiring long-term treatment, in cases where the vertical dimension of the occlusion needs to be changed, in bruxism cases and in areas with excessive occlusal loads [1-4]. Materials with different chemical structures and improved physical properties are available for use in restorations. Polymethylmethacrylate, polymethylmethacrylate bisacryl based, and micro-filled resins are used in the clinic as temporary restoration materials. Different studies have shown that polymethylmethacrylates have lower wear resistance and better esthetic properties than polymethylmethacrylate bis-acryl and micro-filled resins [5, 6].

The oral environment can be very corrosive for dental materials. Depending on his nutritional habits, the contents of the nutrients that an individual consumes and his saliva can react with the materials used in restorations, disrupting their structure and affecting their mechanical and physical properties. Other studies have determined that the resin matrix of dental composites exposed to organic acids and different nutrients softens and that these chemicals cause dissolution in the resin and filler interface [7, 8].

All kinds of foods and beverages in the oral environment can cause tooth discoloration, decay and wear depending on exposure time and the quality of oral hygiene. They can also create changes in the

*email: rona13_rona@hotmail.com 
surface of restorative materials. Beverages, including water, can cause changes in micro-hardness, surface roughness and permeability as well as discoloration and reduced quality in restorative materials [9].

Surface hardness $[10,11]$ and surface roughness [12], which can be affected by various physical and chemical factors, should be considered in terms of the physical properties of restorative materials [10, 11]. Surface roughness, which can cause plaque retention and discoloration, also reduces clinical life $[12,13]$. Polishing is applied to the surfaces of restorative materials to reduce surface roughness as much as possible. Surface roughness, which is the two-dimensional parameter of the material surface, can be measured with a device called a profilometer and expressed numerically [14].

The ability of a material to resist local deformation is defined as hardness [15]. In hardness tests performed by applying pressure for a certain time and with a certain amount of force on the surface of the material, the hardness value is calculated according to the depth and area of the trace created by the pressure. The hardness of the material changes inversely with the size of the trace; the hardness increases as the size decreases and decreases as the size becomes larger. The resulting measurements are expressed with the formula 'load/area' [16].

The $p \mathrm{H}$ in the mouth can drop to 5.5 with sugar consumption and it is recognized that this situation increases the microorganisms that cause decay [17]. The effect of this acidic environment on the surface roughness and hardness of fixed temporary restorative materials needs to be evaluated.

This study aimed to examine roughness and hardness values on the polished and unpolished surfaces of fixed temporary restorative materials caused by acidic drinks such as Coke, the addition of sugar to daily beverages such as tea and coffee, and mouthwash.

The hypothesis of the study is that preparing the material using different methods, solutions, holding periods in solutions and polishing processes would affect the surface hardness and roughness of fixed temporary restoration materials.

\section{Materials and methods}

A $10 \mathrm{~mm}$ diameter metal sheet with a $2 \mathrm{~mm}$ thick hole was used to prepare samples, which were chemically polymerized, cadmium-free polymethylmethacrylate (Imicryl Imident, Konya, Turkey). Powder and liquid were mixed at the rate of $10 \mathrm{~mL} / 24 \mathrm{~g}$ for one minute in each of the molds on the metal placed on the cement glass, as recommended by the manufacturer. To obtain a smooth shape, pressure was applied lightly on the cement glass to facilitate polymerization and 112 samples were obtained.

For specimens with CAD/CAM, 112 samples were prepared from the block (Bornova, Izmir, Turkey) with one dent $10 \mathrm{~mm}$ in diameter and $2 \mathrm{~mm}$ thick. Half of the chemically polymerized samples prepared with CAD/CAM were polished in line with the manufacturer's recommendations while half were left unpolished.

After the samples were numbered, the roughness (Profilometer device Surtronic 25; Taylor Hobson, Leicester, U.K.) and microhardness (Vickers Hardness Tester; TMTeck HV1000B, TMTeck Manufacturing Limited, Beijing, China) values were measured. The average values taken with three measurements from each sample surface were used for surface roughness (Ra). Vickers hardness test was performed by applying $1.96 \mathrm{~N}$ force for $15 \mathrm{~s}$. Samples were randomly divided into seven groups $(\mathrm{n}=8)$. Samples of Coke (Coca-Cola Company, Turkey), distilled water, tea with/without sugar (Lipton Yellow Label, Corlu, Turkey), Turkish coffee with/without sugar (Kurukahveci Mehmet Efendi, the TS 3117, Y. Dudullu, Istanbul) and mouthwash (Listerine ${ }^{\circledR}$ Cool Mint, Johnson and Johnson Plumbing Supplies San. and Tic. Ltd. Sti., Turkey) were kept in $100 \mathrm{~mL}$ plastic containers for $24 \mathrm{~h}$, one week and three weeks. Subsequently, roughness and microhardness values were measured again.

The tea solution was prepared by immersing five prefabricated doses of tea in $500 \mathrm{~mL}$ of boiling water for $10 \mathrm{~min}$. Turkish coffee was prepared by boiling 5-7 g powder in $65 \mathrm{~mL}$ cold distilled water for a few min. Tea and coffee with sugar were prepared by adding $10 \mathrm{~g}$ sugar per $300 \mathrm{~mL}$ of tea or coffee [18]. Distilled water was used as the control. During this study, all solutions were refreshed once a week [19]. 
Statistical evaluations of data and multiple comparisons between groups were made using 3--way analysis of variance (ANOVA) and Tukey HSD test, respectively.

\section{Results and discussions}

As a result of variance analysis made for data evaluation, it was statistically determined that the type of material used is significant $(p<0.05)$, the surface treatment applied is very significant $(p<0.001)$, the holding periods in solutions are significant $(p<0.01)$, the storage solution is insignificant $(p>0.05)$, the surface treatment interaction with the material used is very significant $(p<0.001)$, the surface treatment with the holding time and the solution kept for the holding period is very significant $(p<0.01)$, the triple interaction of storage time/material used/surface preparation method is very significant $(p<0.001)$, the storage time and solution and the interaction between storage time and solution is significant $(p<0.001)$, and the storage time and other interactions are insignificant (material-storage solution, surface processsolution, material-surface process-solution, storage time-surface process-storage solution and storage time/used material/surface process-storage solution). The data obtained for roughness mean and standard deviation ratios are in Table 1.

Table 1. The Means and standard deviation results of the data obtained for roughness $(\mathrm{Ra})(\mathrm{n}=8)$

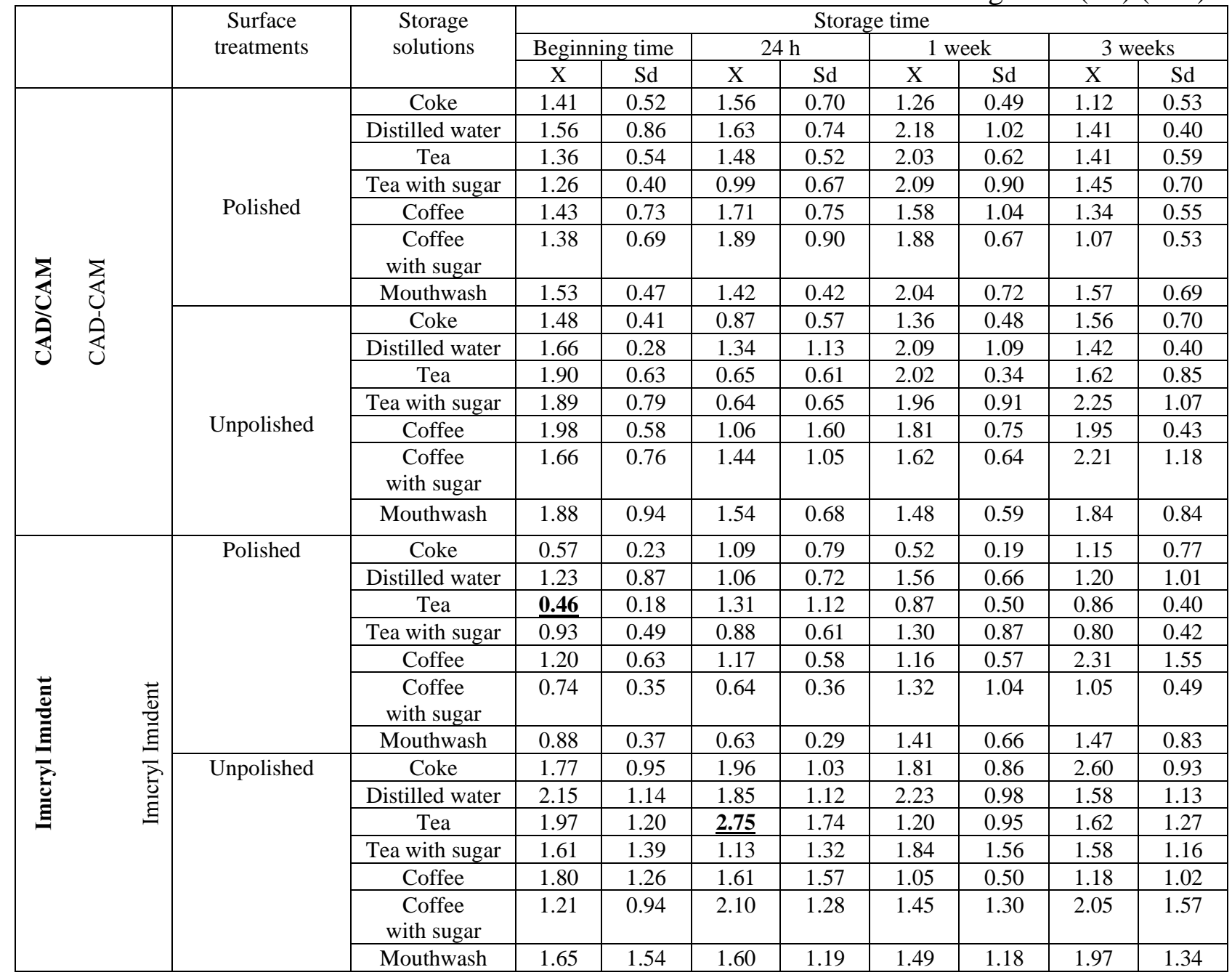

The highest roughness values were seen in the graded samples while the lowest were in the polished samples prepared by traditional methods. The highest roughness value $(2.75 \mathrm{Ra})$ was detected in the measurements of samples prepared with Imicryl Imident unpolished and kept for $24 \mathrm{~h}$ in tea, followed by the samples kept in Coke for three weeks (2.60 Ra). 
The lowest roughness value after holding $(0.52 \mathrm{Ra})$ was measured in samples with polish prepared with Imicryl Imident and kept in Coke for one week.

It was noted that the initial roughness values $(1.53 \mathrm{Ra})$ of polished samples prepared with CADCAM and kept in mouthwash decreased after $24 \mathrm{~h}(1.42 \mathrm{Ra})$ but increased one week later (2.04 Ra). The lowest increase from the initial value was observed with $0.04 \mathrm{Ra}$ after three weeks $(1.57 \mathrm{Ra})$. The maximum increase in value $(1.11 \mathrm{Ra})$ from the initial value up to three weeks was seen in polished samples prepared with Imicryl Imident and kept in coffee. It was determined that the initial roughness values $(1.20 \mathrm{Ra})$ increased after $24 \mathrm{~h}(1.17 \mathrm{Ra})$, one week $(1.16 \mathrm{Ra})$ and three weeks $(2.31 \mathrm{Ra})$.

The lowest decline in value, $0.03 \mathrm{Ra}$, was seen in samples kept in tea with sugar, prepared with Imicryl Imident unpolished. It was determined that the initial roughness values (1.61 Ra) decreased after $24 \mathrm{~h}(1.13 \mathrm{Ra})$, increased one week later $(1.84 \mathrm{Ra})$ and decreased three weeks later $(1.58 \mathrm{Ra})$ in the samples kept in tea with sugar.

The maximum decrease value, $1.02 \mathrm{Ra}$, was seen in samples kept in distilled water prepared with Imicryl Imident unpolished. It was determined that the initial roughness values ( $2.15 \mathrm{Ra})$ decreased after $24 \mathrm{~h}(1.85 \mathrm{Ra})$, increased one week later (2.23 Ra) and decreased three weeks later (1.58 Ra).

In general, it was noted that the roughness values of the samples prepared with Imicryl Imident were higher.

The distribution of the roughness changes of polished and unpolished samples according to time and solution is shown Figures 1,2,3 and 4.

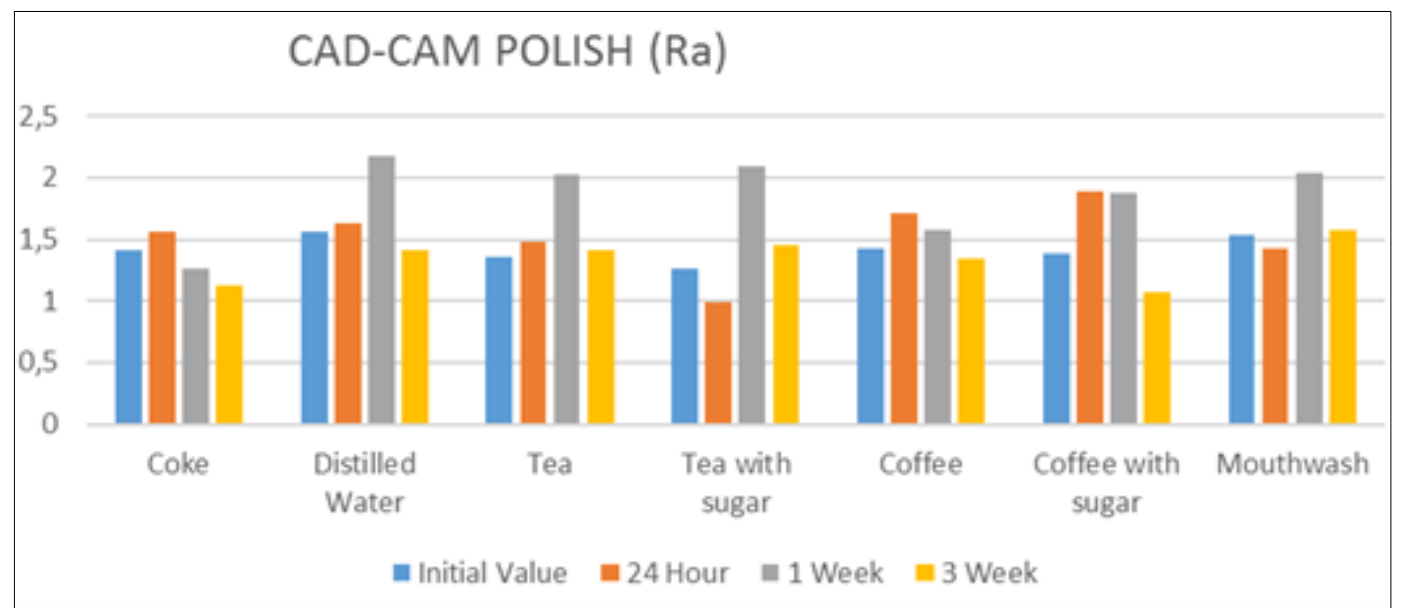

Figure 1. Roughness changes of polished samples prepared with $\mathrm{CAD} / \mathrm{CAM}$ according to solution and time

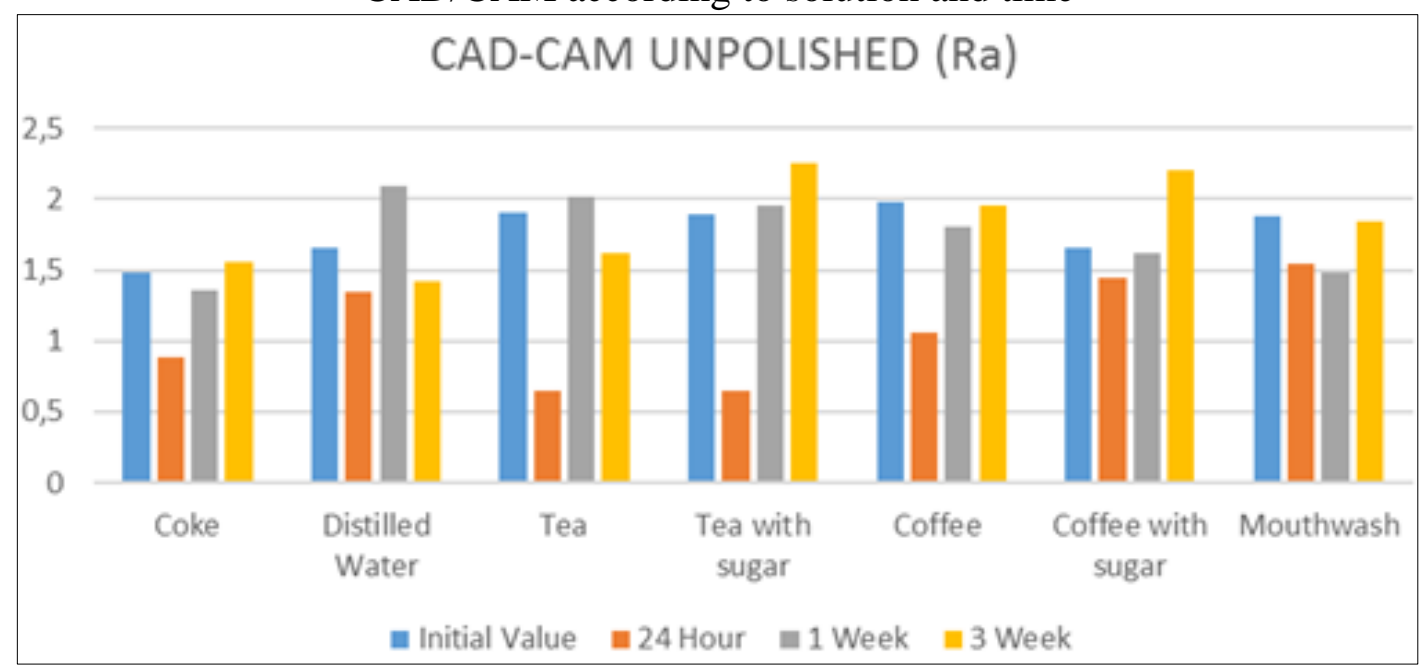

Figure 2. Roughness changes of Unpolished samples prepared with CAD/CAM according to solution and time 


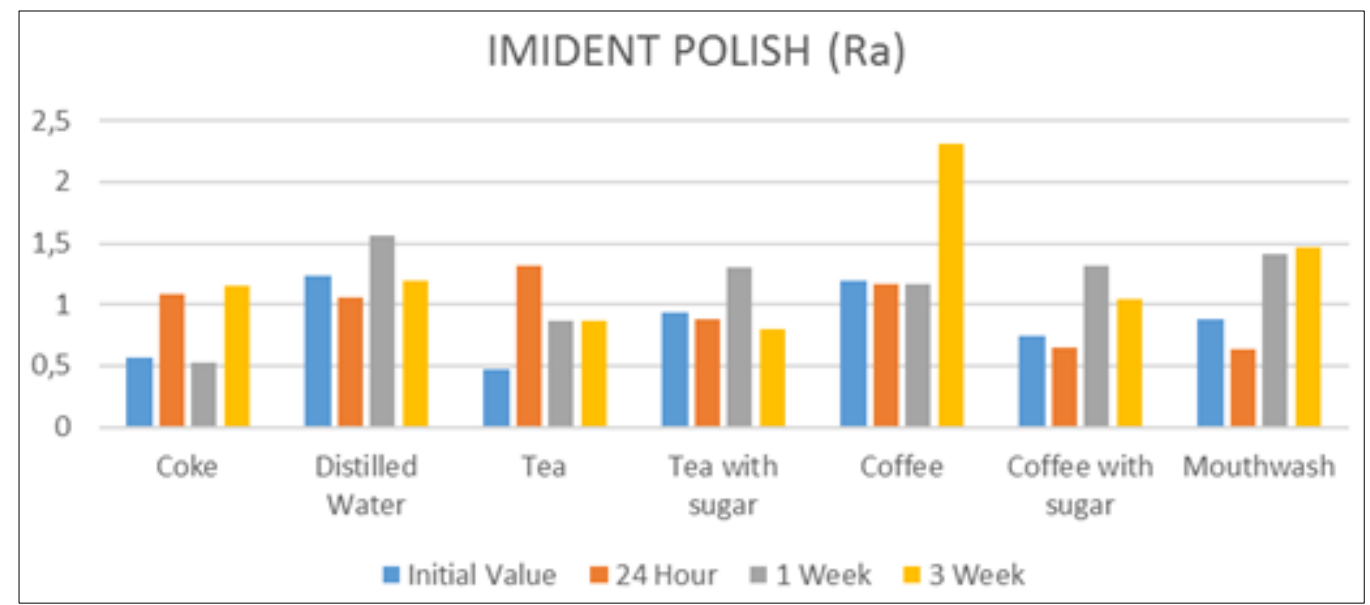

Figure 3. Roughness changes of polished samples prepared with Imicryl Imident according to solution and time

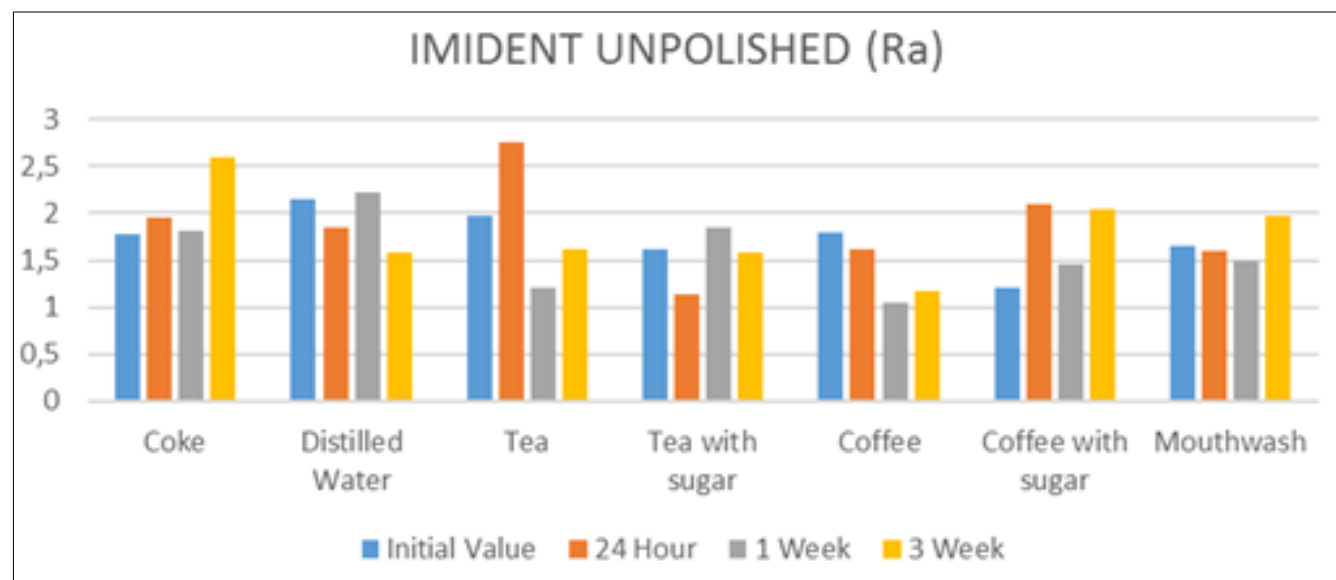

Figure 4. Roughness changes of the samples prepared with Imicryl Imident unpolished according to solution and time

As can be seen in the variance analysis table, the applied surface treatment was statistically highly significant $(p<0.001)$, holding times in solutions were statistically significant $(p<0.01)$, and the type of material used, the holding solution and interactions were statistically insignificant $(p>0.05)$.

The Means and standard deviation results of the hardness values obtained are shown in Table 2 .

Table 2. Means and standard deviation results of the hardness values (HV) $(n=8)$

\begin{tabular}{|c|c|c|c|c|c|c|c|c|c|c|}
\hline \multirow[t]{3}{*}{ Materials } & \multirow{3}{*}{$\begin{array}{l}\text { Surface } \\
\text { treatments }\end{array}$} & \multirow{3}{*}{$\begin{array}{l}\text { Storage } \\
\text { solutions }\end{array}$} & \multicolumn{8}{|c|}{ Storage time } \\
\hline & & & \multicolumn{2}{|c|}{ Beginning time } & \multicolumn{2}{|c|}{$24 \mathrm{~h}$} & \multicolumn{2}{|c|}{1 week } & \multicolumn{2}{|c|}{3 weeks } \\
\hline & & & $\mathrm{X}$ & $\mathrm{Sd}$ & $\mathrm{X}$ & $\mathrm{Sd}$ & $\mathrm{X}$ & $\mathrm{Sd}$ & $\mathrm{X}$ & $\mathrm{Sd}$ \\
\hline \multirow{8}{*}{ 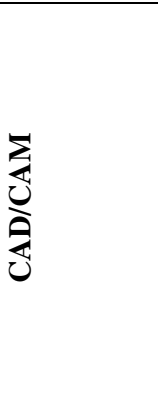 } & \multirow{7}{*}{ Polished } & Coke & 18.5 & 2.77 & 20.4 & 8.02 & 19.0 & 1.59 & 17.5 & 1.07 \\
\hline & & $\begin{array}{l}\text { Distilled } \\
\text { water }\end{array}$ & 17.5 & 0.86 & 18.3 & 2.11 & 17.7 & 1.25 & 16.6 & 1.22 \\
\hline & & Tea & 17.9 & 0.65 & 19.4 & 4.16 & 17.5 & 1.43 & 16.6 & 1.10 \\
\hline & & $\begin{array}{l}\text { Tea with } \\
\text { sugar }\end{array}$ & 15.5 & 0.92 & 16.3 & 1.24 & 17.1 & 0.507 & 16.6 & 1.10 \\
\hline & & Coffee & 20.5 & 10.7 & 18.1 & 2.88 & 17.2 & 1.14 & 18.0 & 3.59 \\
\hline & & $\begin{array}{c}\text { Coffee } \\
\text { with sugar }\end{array}$ & 17.2 & 1.12 & 21.3 & 3.09 & 20.0 & 7.01 & 16.5 & 1.95 \\
\hline & & Mouthwash & 16.2 & 3.04 & 16.5 & 2.69 & 16.8 & 3.43 & 15.0 & 2.42 \\
\hline & & Coke & 39.1 & 30.0 & 48.2 & 43.7 & 58.2 & 60.6 & 23.0 & 6.02 \\
\hline
\end{tabular}




\begin{tabular}{|c|c|c|c|c|c|c|c|c|c|c|}
\hline & \multirow[t]{6}{*}{ Unpolished } & $\begin{array}{l}\text { Distilled } \\
\text { water }\end{array}$ & 33.4 & 29.5 & 41.2 & 28.8 & 21.4 & 2.89 & 22.3 & 6.44 \\
\hline & & Tea & 33.0 & 13.9 & 29.3 & 14.5 & 21.2 & 2.24 & 26.9 & 17.0 \\
\hline & & $\begin{array}{c}\text { Tea with } \\
\text { sugar }\end{array}$ & 41.3 & 58.2 & 49.2 & 62.0 & 17.6 & 2.61 & 18.8 & 4.72 \\
\hline & & Coffee & 23.8 & 4.99 & 21.3 & 4.21 & 25.0 & 7.22 & 21.5 & 6.53 \\
\hline & & $\begin{array}{c}\text { Coffee } \\
\text { with sugar }\end{array}$ & 36.3 & 41.1 & 34.6 & 24.1 & 22.0 & 6.70 & 26.4 & 18.5 \\
\hline & & Gargara & 32.1 & 19.3 & 18.6 & 3.22 & 20.6 & 6.68 & 13.5 & 1.66 \\
\hline \multirow{14}{*}{ 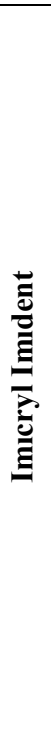 } & \multirow[t]{7}{*}{ Polished } & Coke & 13.5 & 1.93 & 14.5 & 3.03 & 24.0 & 27.9 & 20.2 & 18.0 \\
\hline & & $\begin{array}{l}\text { Distilled } \\
\text { water }\end{array}$ & 14.9 & 0.95 & 15.9 & 1.37 & 16.1 & 3.29 & 14.5 & 0.979 \\
\hline & & Tea & 17.3 & 8.57 & 15.6 & 3.48 & 15.1 & 1.59 & 14.4 & 0.921 \\
\hline & & $\begin{array}{l}\text { Tea with } \\
\text { sugar }\end{array}$ & 16.5 & 7.45 & 13.0 & 3.87 & 33.3 & 43.1 & 15.5 & 4.50 \\
\hline & & Coffee & 14.3 & 1.20 & 13.5 & 1.96 & 21.3 & 14.3 & 17.6 & 9.47 \\
\hline & & $\begin{array}{c}\text { Coffee } \\
\text { with sugar }\end{array}$ & 22.2 & 16.5 & 16.0 & 3.30 & 20.4 & 11.9 & 14.9 & 1.30 \\
\hline & & Gargara & 14.5 & 0.87 & 13.1 & 1.33 & 14.2 & 2.04 & 10.0 & 3.07 \\
\hline & \multirow[t]{7}{*}{ Unpolished } & Coke & 25.6 & 34.9 & 25.7 & 28.8 & 30.3 & 35.4 & 28.5 & 25.6 \\
\hline & & $\begin{array}{c}\text { Distilled } \\
\text { water }\end{array}$ & 28.5 & 41.2 & 24.1 & 12.9 & 24.0 & 10.4 & 14.9 & 3.20 \\
\hline & & Tea & 35.7 & 27.2 & 38.9 & 39.2 & 29.6 & 23.6 & 21.2 & 5.90 \\
\hline & & $\begin{array}{c}\text { Tea with } \\
\text { sugar }\end{array}$ & 25.2 & 16.3 & 16.3 & 4.42 & 32.5 & 19.7 & 16.1 & 3.10 \\
\hline & & Coffee & 40.5 & 64.8 & 22.3 & 22.2 & 25.3 & 20.6 & 32.4 & 39.6 \\
\hline & & $\begin{array}{c}\text { Coffee } \\
\text { with sugar }\end{array}$ & 56.5 & 93.1 & 41.6 & 29.5 & 38.7 & 31.0 & 23.0 & 14.3 \\
\hline & & Gargara & 21.4 & 10.6 & 55.8 & 1.17 & 16.2 & 4.44 & 16.5 & 7.48 \\
\hline
\end{tabular}

The highest hardness value, $58.2 \mathrm{HV}$, was seen in the measurements after one week in the samples that were graded, prepared with CAD/CAM, and kept in Coke. That was followed by $55.8 \mathrm{HV}$ taken after $24 \mathrm{~h}$ of samples prepared with Imicryl Imident grading and kept in mouthwash.

The lowest hardness value $(10.00 \mathrm{HV})$ was seen in the measurements of polished samples prepared with Imicryl Imident and kept in mouthwash for three weeks.

It was noted that initial hardness values $(15.5 \mathrm{HV})$ of samples kept in tea with sugar, polished and prepared with CAD-CAM increased after $24 \mathrm{~h}(16.3 \mathrm{HV})$, increased one week later $(17.1 \mathrm{HV})$, and three weeks later $(16.6 \mathrm{HV})$ there was the least increase in the hardness value from the initial value with 1.1 $\mathrm{HV}$. The highest hardness value increase $(6.7 \mathrm{HV})$ up to three weeks after the initial value was seen in the samples kept in Coke, polished, and prepared with Imicryl Imident. It was determined that the highest changes from the initial hardness values $(13.5 \mathrm{HV})$ were after $24 \mathrm{~h}(14.5 \mathrm{HV})$, after one week $(24.0 \mathrm{HV})$ and after three weeks $(20.2 \mathrm{HV})$.

The least decline value, $0.4 \mathrm{HV}$, was seen in samples that were polished, prepared with Imicryl Imident and kept in distilled water. It was determined that the initial hardness values $(14.9 \mathrm{HV})$ increased after $24 \mathrm{~h}(15.9 \mathrm{HV})$, increased one week later $(16.1 \mathrm{HV})$ and showed the least decrease compared to the initial value after three weeks (14.5 HV).

The maximum decrease value, $33.5 \mathrm{HV}$, was seen in samples prepared with Imicryl Imident grading and kept in coffee with sugar. It was found that the initial hardness values decreased after $24 \mathrm{~h} \mathrm{(41.6}$ $\mathrm{HV}$ ) after one week (38.7 HV) and after three weeks (23.0 HV).

The distribution of the average hardness values of the samples according to holding solution and time is shown in Figure 5. 


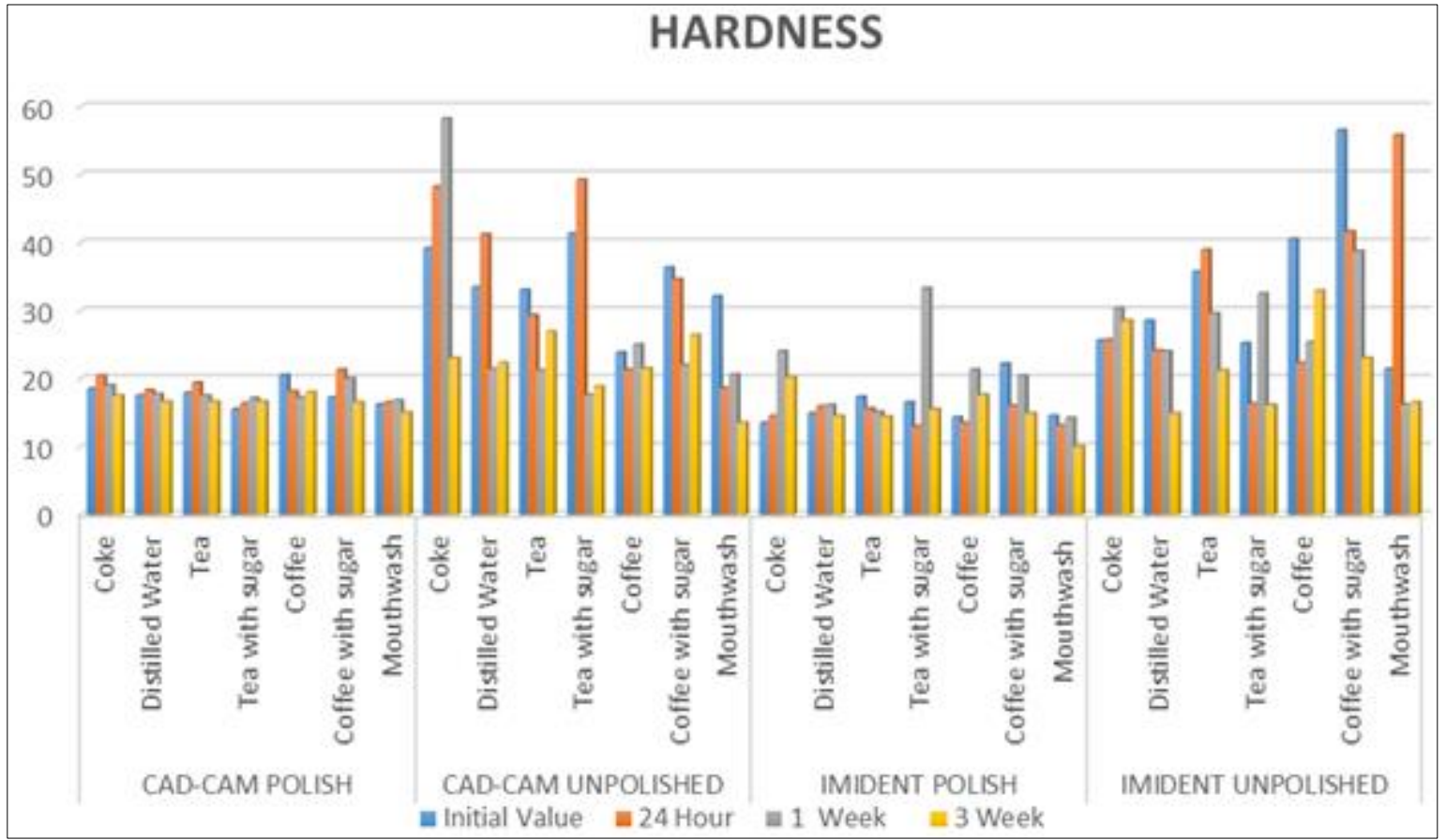

Figure 5. Hardness values of temporary restorative materials

According to the statistical results, the difference between the materials is not significant $(p>0.05)$ and the surface treatment is highly significant $(p<0.001)$.

In dentistry applications, it is important to know the physical and mechanical properties of materials so the right one can be selected to meet treatment needs. Proper material selection increases treatment success rates [10].

The roughness value of the surface of the restorative materials used in dentistry is an important factor that can cause discoloration, bacterial colonization and irritation in the gingiva, deterioration of the edge integrity and erosion of the material. Accordingly, finishing and polishing processes before cementation in the mouth will significantly increase the patient's satisfaction and ensure successful restoration [20, 21].

As a result of this study, part of the hypothesis was accepted since it was determined that polishing affects the surface hardness and roughness of the fixed temporary restoration material whereas differences in the kept solution do not.

Tekce et al. [22] reported that the surface roughness of restorative materials produced with CAD/CAM was significantly reduced when polished.

Bollen et al. [23] emphasized that the average surface roughness value of the materials used in the mouth should be below $0.2 \mu \mathrm{m}$. It was stated by Biçer et al [24] that the average surface roughness value of the restorative material should be lower than $1 \mu \mathrm{m}$ in order to exert an optically smooth restoration surface.

Many researchers studying PMMA report that the degree of conversion of the monomer structure to polymer is related to the mechanical properties. Based on this, they emphasize that the transformation degree can be measured easily by knowing the hardness of the materials $[10,25,26]$. It is argued that resins in which polymerization is provided by the conversion of the monomer will have fewer residual monomers [27]. At the same time, it has been reported that the abrasion resistance is higher in resins where this transformation is more intense [25]. When the conversion degree of monomer to polymer decreases, water absorption increases and resistance to abrasion decreases with the increase of residual monomer released into the environment [28]. Stawarczyk et al [29] studied CAD/CAM resin blocks and reported that the surface properties and hardness of the resin are critical factors that cause erosion in antagonist teeth. 
Surface hardness is a numerical expression of measurement of material resistance against the pressure that is generated by immersing a conical or spherical tip in the material [30]. Hardness measurements can be made with the Brinell, Rockwell, Vickers, and Knoop methods. It has been reported that Vickers and Knoop tests can be used for many of the materials in dentistry [31-33]. In this study, surface hardness was measured with the Vickers hardness test. The amount of load used to press the material is important in all hardness tests [34, 35]. Applying excessive force to stretchable materials can cause cracks, which may result in incorrect results [36]. Consequently, in this study, $1.96 \mathrm{~N}$ force was applied for about $15 \mathrm{~s}$.

The diamond tip of the profilometer used in the measurement of surface roughness can move on the sample surface and measure small surface variations [37]. The "Ra" parameter was used for the profilometer used in the studies for the roughness of dental materials [37, 38]. Measurements with the same type of device allow comparison with the many other studies in the literature [10]. The devices used for hardness and roughness measurements in the current study are those devices most frequently reported to have been used in such measurements by other researchers $[11,12,35]$.

The acid type and ratio in the beverage, the concentration of the beverage, the duration and frequency of contact between the prosthetic material and the beverage, the content of the prosthetic material, the type of hardness tester, the load applied during measurement and the holding time are factors affecting the surface hardness of the materials [35, 39].

Lee et al [40] obtained information about the transformations of autopolymerizing acrylic resins that polymerize under different temperatures and pressures by comparing their hardness values. They stated that resins polymerized in water at high temperatures are harder.

Since the polymerization of the superficial layer where oxygen contact cannot be interrupted is less than the lower layers, the abrasion of this layer [21] as a result of finishing and polishing processes provides harder surfaces. The result is a more durable and esthetic restoration surface [41, 42]. All materials used in prosthetic dental treatment are exposed to decomposition caused by bacteria that use debris left from the food and beverages consumed during the day and the effects of the acidic environment that results [43]. It has been reported that the surface hardness of many restorative materials decreases due to this exposure [44].

It has also been reported that one week after opening acidic beverages such as Coke the $\mathrm{pH}$ does not change but the beverage loses its gas [44]. In this study, a new Coke $(330 \mathrm{~mL})$ was used for each measurement.

Chung and Yap [45] reported in their study that the finishing and polishing process applied to composite and compomer restorative materials had no effect on surface hardness and roughness [46]. On the other hand, Lee et al [40] applied three-year aging to composite samples and reported that the surface polished composite materials made a difference but there was no significant difference in the surface roughness of different types of composites.

In a study comparing traditionally prepared and CAD/CAM temporary crowns, the CAD/CAMproduced temporary crowns showed improved color stability and physical and mechanical properties [47]. However, Burduroğlu [10] reported in a study on the mechanical properties of CAD/CAM and heat-polymerized temporary crowns that in the long-term CAD/CAM materials had no significant mechanical advantage over traditional materials. He recommended that transients requiring long-term use should be heat-polymerized [10]. It is important that all materials used in such studies have standard properties [31]. Therefore, the materials we standardized in terms of thickness and diameter were prepared in one color (A2). The materials used in the assessment of surface hardness and roughness are generally prepared in the form of a disc with a flat surface. However, no surface is flat in the mouth environment. The polishing process is also more easily effected on flat surfaces. One of the limitations of our study is that it is not possible to polish recessed surfaces, especially on the occlusal surfaces of the teeth. However, the use of flat surface materials in all in vitro studies is important in terms of being comparable [10]. 
It has been reported that changes in hardness values caused by the exposure of composite resins to different solutions occur within the first seven days [48]. This period is a long time considering the instant contact of the teeth with food during eating. However, these chemical agents can accumulate on the margins and joints of temporary dentures with poorly polished and rough surfaces. In addition, existing calculus and additions in margins can significantly increase exposure time by creating host sites well-suited to the accumulation of the chemical agents in question. It should also be recognized that in clinical conditions patients have to use temporary teeth for several months. In a study by Güler et al. [49], it was stated that the liquid could be in contact with the tissues in the mouth for 15 min for each cup of coffee consumed, and an average consumption of 3.20 cups per day was mentioned. With that in mind, the $24 \mathrm{~h}$ holding period will simulate the consumption of the beverage for more than one month. However, there may be substantial differences in the consumption of food and beverages among different people. While some individuals consume no coffee or tea, they might consume a lot of Coke. During periods when nothing is consumed in the oral environment, moisture and temperature can affect materials. It is important to know how the surface properties are affected when temporary materials stay in the oral environment for much longer than one day. In this respect, it is important to have longer holding periods than the one day, one week and three weeks in the present study. Limitations of our study include not using artificial saliva and not being able to imitate the mouth environment.

The surface polishing quality of restorative materials closely affects their resistance to chemical solutions [50]. The surface polishes of test samples that did not have the polishing process applied were standardized by polymerizing between glass plates.

In the current study, the highest increase in surface roughness was observed in materials kept in coffee and with polish prepared by the traditional method. The highest hardness value was seen in materials prepared with CAD/CAM, unpolished and kept in Coke for one week. The materials whose hardness values varied the least according to time and solution were materials prepared with CAD/CAM to which polishing was applied. In this respect, acrylic resin samples prepared with the traditional polishing method were in second place. This suggests that polished materials prepared with CAD/CAM may have a longer life. At the same time, it can be said that the polishing process applied to the surface is quite significant.

There are studies reporting that food and beverages affect the mechanical properties of polymers in the mouth by causing structural degradation and softening $[48,51,52]$. It is accepted that acids behave differently in dissolving dental materials and tissues. Although it contains phosphoric acid, it has been suggested that the phosphate ions in Coke can play a role in preventing dissolution by reducing the dissolution from the tooth [18, 53-58]. In the present study, the hardness values of the samples kept in Coke increased in the first week and started to decrease after three weeks of measurements. While the three-week hardness values were lower than the initial value in the samples prepared with CAD/CAM, conversely the hardness increased in the samples prepared by the traditional method. This makes us think that the material type is important in being affected by Coke. A comparison of the initial and threeweek results of the surface roughness values showed an increase except for the CAD/CAM polished groups. This suggests that the polishing process applied to materials prepared with CAD/CAM against acidic beverages such as Coke may increase the mechanical properties.

\section{Conclusions}

According to the statistical results, it can be said that the material type and polishing process are more significant than holding solutions in the present study. However, when we evaluate each group within itself, it can be said that the hardness value decreases more through sugar addition compared to sugar-free tea and coffee at the initial and third-week values. It was determined that the hardness value of the samples kept in mouthwash solution decreased, and this decrease was more in materials without surface treatment. It was found that the addition of sugar did not have a significant effect on the change of roughness values. Although the roughness of the samples kept in mouthwash increased, it decreased 
in the unpolished CAD/CAM samples. This suggests that the solution contents may be insignificant in roughness values.

Within the limits of this study, the materials tested were affected by storage solutions. Materials produced with $\mathrm{CAD} / \mathrm{CAM}$ were found to be more resistant to chemical solutions.

We believe that patients should be warned about their diet, especially when long-term temporary restoration is required.

\section{References}

1.GOLDBERG AJ, BURSTONE CJ., The use of continuous fiber reinforcement in dentistry. Dent Mater 1992; 8:197-202. doi: 10.1016/0109-5641(92)90083-o.

2. MALQUARTI G, BERRUET RG, BOIS D., Prosthetic use of carbon fiber-reinforced epoxy resin for esthetic crowns and fixed partial dentures. J Prosthet Dent 1990; 63:251-257.

doi: 10.1016/0022-3913(90)90190-n.

3.HAMZA TA, ROSENSTIEL SF, ELHOSARY MM, IBRAHEEM RM., The effect of fiber reinforcement on the fracture toughness and flexural strength of provisional restorative resins. J Prosthet Dent 2004; 91:258-264. doi: 10.1016/j.prosdent.2004.01.005.

4.PFEIFFER P, GRUBE L., In vitro resistance of reinforced interim fixed partial dentures. J Prosthet Dent 2003; 89:170-174. doi: 10.1067/mpr.2003.29.

5. KRUG RS., Temporary resin crown and bridges. Dent Clin N Am 1975; 19:313-320.

6.SHILLINBURG HT, HOBO S, WHITSETT LD, JACOBI R, BRACKETT SE., Provisional restorations. Fundamentals of fixed prosthodontics. 3rd ed. Illinois: Quintessence Publishing Co, Inc, 1997: pp. 225-257.

7.AKOVA T, OZKOMUR A, UYSAL H., Effect of food simulating liquids on the mechanical properties of provisional restorative material. Dent Mater 2006; 22:1130-1134.

doi: 10.1016/j.dental.2005.09.009.

8.AKOVA T, OZKOMUR A, AYTUTULDU N, TOROGLU MS., The effect of food simulants on porcelain composite bonding. Dent Mater 2007; 23:1369-1372. doi: 10.1016/j.dental.2006.11.021.

9.DIETSCHI D, CAMPANILE G, HOLZ J, MEYER JM. Comparison of the color stability of ten newgeneration composites: an in vitro study. Dent Mater 1994; 10:353-362.

doi: 10.1016/0109-5641(94)90059-0.

10. BURDUROĞLU HD., Çeşitli Geçici Kron Materyallerinin Mekanik ve Fiziksel Özelliklerinin inVitro Karşılaştırılması (In-vitro comparison of mechanical and physical properties of various provisional restoration materials) Hacettepe University Institute of Health Sciences, Ph.D. Thesis in Prosthodontics, Ankara, 2015

11.ÖZAK ŞT., Farkli yapidaki yapay dişlerin mikrosertlik, yüzey pürüzlülüğü ve renk stabilitesi üzerine değişik sivi ortamlarinin etkisinin değerlendirilmesi (The evaluation of different beverages? effect on the microhardness, surface roughness and colour stability of different denture teeth) Ankara University Institute of Health Sciences, Ph.D. Thesis in Prosthodontics, Ankara, 2012.

12. WATANABE T., MIYAZAKI M., TAKAMIZAWA T., KUROKAWA H., RIKUTA A., ANDO S., Influence of polishing duration on surface roughness of resin composites. J Oral Sci 2005; 47:21-25. doi: 10.2334 /josnusd.47.21.

13. OZEL E., KORKMAZ Y., ATTAR N., KARABULUT E., Effect of one-step polishing systems on surface roughness of different flowable restorative materials. Dent Mater J 2008; 27:755-764.

doi: $10.4012 / \mathrm{dmj} .27 .755$.

14.WAN BAKAR W., MCINTYRE J., Susceptibility of selected tooth-coloured dental materials to damage by common erosive acids. Aust Dent J 2008; 53:226-234.

doi: 10.1111/j.1834-7819.2008.00053.x

15. ANUSAVICE K.J., Phillip's Science of Dental Materials (Ed 11). St. Louis, W.B. Saunders, 2003; pp. 73-102. 
16.O'BRIEN WJ., Dental Materials and their Selection. 3rd Ed., Chicago, USA: Quintessence Publishing, 2002: Chapter 10.

17.USMEN E., Beslenme ve Diş Hekimliği Arasında Etkileşmeler (Interactions Between Nutrition and Dentistry) Journal of Nutrition and Dietetics.1975;4:1-9. Available from:

https://beslenmevediyetdergisi.org/index.php/bdd/article/view/1013

18. BERBER A, CAKIR FY, BASEREN M, GURGANET S., Effect of different polishing systems and drinks on the color stability of resin composite. J Contemp Dent Pract 2013; 14:662-667.

doi: 10.5005/jp-journals-10024-1382.

19.YEŞIL DUYMUŞ Z., YANIKOĞLU N., ARIK M., Evaluation of Colour Changed of Acrylic Resin Materials in the Different Solutions. Asian Journal of Chemistry. 2010; 22:6669-6676.

20. KARAHANLI IA., Farklı yüzey işlemleri uygulanmış alaşım gruplarına bakteri tutunmasının in vitro olarak değerlendirilmesi (In vitro evaluation of the bacterial retention to dental alloy surfaces subjected to different surface treatments) Ankara University Institute of Health Sciences, Ph.D. Thesis in Prosthodontics, Ankara, 2002.

21. RYBA T.M., DUN N.W.J., MURCHISON D.F., Surface roughness of various packable composites. Oper Dent 2003; 27:243-247.

22. TEKÇE N, FIDAN S, TUNCER S, KARA D, DEMIRCI M., The effect of glazing and aging on the surface properties of CAD/CAM resin blocks. J Adv Prosthodont 2018; 10:50-57.

doi: 10.4047/jap.2018.10.1.50.

23. BOLLEN C.M.L., LAMBRECHTS P., QUIRYNEN M., Comparison of surface roughness of oral hard materials to the threshold surface roughness for bacterial plaque retention: a review of the literature. Dent Mater 1997; 13:258-269. doi: 10.1016/s0109-5641(97)80038-3.

24. BIÇER C.Ö., Ö.Z. F.D., ATTAR, N., KORKMAZ, Y., Farklı polisaj sistemlerinin estetik kompozit rezinlerin yüzey pürüzlülüğü üzerine etkileri (Effects of different polishing systems on the surface roughness of esthetic composite resins) Acta Odontol Turc 2017; 34:7780.

doi: $10.17214 /$ gaziaot.277972

25.ASMUSSEN, E., Factors affecting the quantity of remaining double bonds in restorative resin polymers. Scand J Dent Res 1982; 90:490-496. doi: 10.1111/j.1600-0722.1982.tb00767.x.

26. RUYTER, I.E., Methacrylate-based polymeric dental materials: conversion and related properties. Summary and review. Acta Odontologica Scand 1982; 40:359-376. doi: 10.3109/00016358209024081

27. LEE, S.Y., LAI, Y.L., HSU, T.S., Influence of polymerization conditions on monomer elution and microhardness of autopolymerized polymethyl methacrylate resin. Eur J Oral Scienc 2002; 110:179183. doi:10.1034/j.1600-0722.2002.11232.x

28.THOMPSON GA., LUO Q., Contribution of postpolymerization conditioning and storage environments to the mechanical properties of three interim restorative materials. J Prosthet Dent 2014;112: 638648. doi: 10.1016/j.prosdent.2014.04.008.

29. STAWARCZYK B., ÖZCAN M., TROTTMANN A., SCHMUTZ F., ROOS M., HÄMMERLE C., Two-body wear rate of CAD/CAM resin blocks and their enamel antagonists. J Prosthet Dent 2013; 109:325-332. doi: 10.1016/S0022-3913(13)60309-1.

30.ŞENER Y., KOYUTÜRK A.E., Üç farklı cam iyonomer simanın yüzey sertliklerinin karşılaştırılması (The comparison of the surface hardness of three different glass ionomer cements). Cumhuriyet Dent J. 2006;9: 91-94.

31. AMAECHI B.T., HIGHAM S.M., EDGAR W.M., MILOSEVIC A., Thickness of acquired salivary pellicle as a determinant of the sites of dental erosion. J Dent Res 1999; 78:1821-1828.

doi: $10.1177 / 00220345990780120901$

32.ORTENGREN U., WELLENDORF H., KARLSSON S., RUYTER IE., Water sorption and solubility of dental composites and identification of monomers released in an aqueous environment. J Oral Rehabil 2001; 28:1106-1115. doi: 10.1046/j.1365-2842.2001.00802.x.

33.TAHMASSEBI JF, DUGGAL MS, MALIK-KOTRU G, CURZON ME. Soft drinks and dental health: a review of the current literature. J Dent 2006; 34:2-11. doi: 10.1016/j.jdent.2004.11.006. 
34.JONIOT SB, GRÉGOIRE GL, AUTHER AM, ROQUES YM. Three dimensional optical profilometry analysis of surface states obtained after finishing sequences for three composite resins. Oper Dent 2000; 25:311-315.

35.SARI D., KOYUTÜRK D., ÇANKAYA D., Günlük Tüketilen Yiyecek ve İçeceklerin Mine ve Dolgu Materyallerinin Yüzey Sertliği Ve Pürüzlülüğüne Etkisi (Effects on the surface hardness and surface roughness of restorative materials and enamel of daily consumed foods and beverages) J Dent Fac Atatürk Uni. 2010; 20: 153-161. Retrieved from https://dergipark.org.tr/tr/pub/ataunidfd/issue/2479/ 31724

36. REIS A.F., GIANNINI M., LOVADINO J.R., DOS SANTOS DIAS C.T., The effect of six polishing systems on the surface roughness of two packable resin based composites. Am J Dent 2002; 15:193-197. 37. MAHROSS HZ, MOHAMED MD, HASSAN AM, BAROUDI K. Effect of Cigarette Smoke on Surface Roughness of Different Denture Base Materials. J Clin Diagn Res 2015;9: ZC39-ZC42. doi: 10.7860/JCDR/2015/14580.6488.

38. MACHADO A.L., BREEDING L.C., VERGANI C.E., da CRUZ PEREZ L.E., Hardness and surface roughness of reline and denture base acrylic resins after repeated disinfection procedures. J Prosthet Dent. 2009 Aug;102(2):115-22. doi: 10.1016/S0022-3913(09)60120-7.

39.YAP AUJ, LOW J.S., ONG LFKL, Effect of food simulating liquids on surface characteristics of composite and polyacid-modified composite restoratives. Oper Dent 2000; 25:170-176.

40.LEE YK, LU H, OGURI M, POWERS JM. Changes in gloss after simulated generalized wear of composite resin. J Prosthet Dent 2005; 94:370-376. doi: 10.1016/j.prosdent.2005.08.006.

41.STODDARD J.W., JOHNSON G.H., An evaluation of polishing agents for composite resins. J Prosthet Dent 1991; 65:491-495. doi: 10.1016/0022-3913(91)90286-6.

42. SCHEIBE K.G., ALMEIDA K.G., MEDEIROS I.S., COSTA J.F., ALVES C.M., Effect of different polishing systems on the surface roughness of microhybrid composites. J Applied Oral Sciences 2009;17: 21-26. doi: 10.1590/s1678-77572009000100005.

43.RIOS D., HONÓRIO H.M., FRANCISCONI L.F., MAGALHÃES A.C., DE ANDRADE MOREIRA MACHADO M.A., BUZALAF M.A., In situ effect of an erosive challange on different restorative materials and on enamel adjacent to these materials. J Dent 2008; 36:152-157.

doi: 10.1016/i.jdent.2007.11.013.

44.ALIPING-MCKENZIE M., LINDEN R.W.A., NICHOLSON J.W., The effect of Coca-Cola and fruit juices on the surface hardness of glass-ionomers and 'compomers'. J Oral Rehabil 2004; 31:1046-1052. doi: 10.1111/j.1365-2842.2004.01348.x.

45.CHUNG S.M., YAP A.U.J., Effects of surface finish on indentation modulus and hardness of dental composite restoratives. Dent Mater 2005; 21:1008-1016. doi: 10.1016/j.dental.2004.11.006.

46.KÜÇÜKEŞMEN H.C., KÜÇÜKEŞMEN Ç., ÜŞÜMEZ A., Yaşlandırma Prosedürünün Farklı Restoratif Materyallerin Yüzey Pürüzlülüğü Üzerine Etkisi (Examination of effect of aging procedure on surface roughness of different restorative materials) Suleyman Demirel University Journal of Health Sciences. 2010; 1:39-49.

47.RAYYAN M.M., ABOUSHELIB M., SAYED N.M., IBRAHIM A., JIMBO R., Comparison of interim restorations fabricated by CAD/CAM with those fabricated manually. J Prosthet Dent 2015; 114:414-419. doi: 10.1016/j.prosdent.2015.03.007.

48.KAO E.C., Influence of food-simulating solvents on resin composites and glass-ionomer restorative cement. Dent Mater. 1989; 5:201-208. doi: 10.1016/0109-5641(89)90014-6.

49.GULER A.U., YILMAZ F., KULUNK T., GULER E., KURT S., Effects of different drinks on stainability of resin composite provisional restorative materials. J Prosthet Dent 2005; 94:118-124. doi: 10.1016/j.prosdent.2005.05.004.

50.YAP A.U., MAH M.K., LYE C.P., LOH P.L., Influence of dietary simulating solvents on the hardness of provisional restorative materials. Dent Mater 2004; 20:370-376.

doi: 10.1016/j.dental.2003.06.001. 
51.YAP A.U., CHEW C.L., ONG L.F., TEOH S.H., Environmental damage and occlusal contact area wear of composite restoratives. J Oral Rehabil 2002; 29:87-97. doi: 10.1046/j.1365-2842.2002.00797.x. 52.EKREN O., ÖZKÖMÜR A., GÜRBÜZ C.C., Besin Taklidi Sıvıların Üç Farklı Geçici Kron Materyalinin Yüzey Sertliğine Etkisi (The effects of food-simulating liquids on the hardness of three different provisional crown materials) Journal of Ege University School of Dentistry. 2014;3:23-27. doi: $10.5505 /$ eudfd.2014.28247

53. TOPCU F.T., SAHINKESEN G., YAMANEL K., ERDEMIR U., OKTAY E.A., ERSAHAN S., Influence of different drinks on the colour stability of dental resin composites. Eur J Dent 2009;3: 5056.

54.ERTAŞ E., GÜLER A.U., YÜCEL A.C., KÖPRÜLÜ H., GÜLER E., Color stability of resin composites after immersion in different drinks. Dent Mater J. 2006; 25:371-376.

55.POGGIO C., DAGNA A., CHIESA M., COLOMBO M., SCRIBANTE A., Surface roughness of flowable resin composites eroded by acidic and alcoholic drinks. J Conserv Dent 2012; 15:137-140. doi: 10.4103/0972-0707.94581.

56.CATELAN A., BRISO A.L., SUNDFELD R.H., DOS SANTOS P.H., Effect of artificial aging on the roughness and microhardness of sealed composites. J Esthet Restor Dent 2010; 22:324-330.

doi: $10.1111 / \mathrm{j} .1708-8240.2010 .00360 . x$.

57. ARDU S., BRAUT V., GUTEMBERG D., KREJCI I., DIETSCHI D., FEILZER A.J., A long-term laboratory test on staining susceptibility of esthetic composite resin materials. Quintessence Int 41:695702.

58. MUNDIM F.M., GARCIA LDA F., PIRES-DE-SOUZA FDE C., Effect of staining solutions and repolishing on color stability of direct composites. J Appl Oral Sci 2010; 18:249-254.

doi: 10.1590/s1678-77572010000300009

Manuscript received: 24.08 .2021 